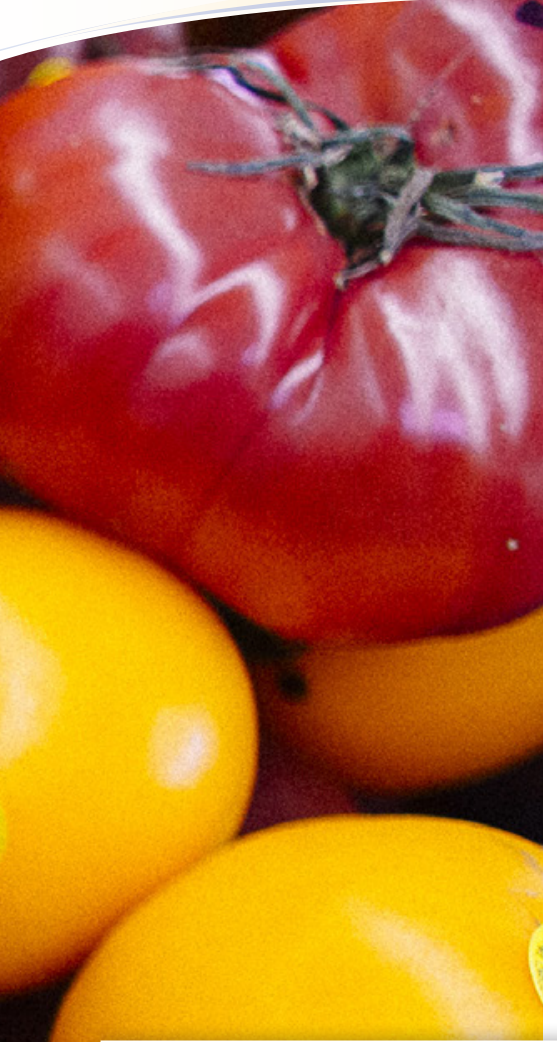

KRIS GODFREY, University of California, Davis, Contained Research Facility;

FRANK ZALOM, University of California, Davis, Department of Entomology and Nematology; and JOANNA CHIU, University of California, Davis, Department of Entomology and Nematology

\title{
Tuta Absoluta, The South American Tomato Leafminer
}

\section{$\mathrm{T}$} he South American tomato leafminer, Tuta absoluta Meyrick (Lepidoptera: Gelechiidae), is a serious and devastating pest of fresh market and processing tomatoes (fig. 1). Tuta absoluta, or Tuta, as it is also known, is thought to be native to South America. Currently, Tuta can be found in South America, southern Central America, southern Europe, northern Africa, the Middle East, and in localized parts of India (CABI 2016). Tuta is continuing to spread throughout the tomato-growing areas of the world (Desneux et al. 2010). Although it has not been reported in California or elsewhere in the United States, computer models that are used to match the life history of an invasive

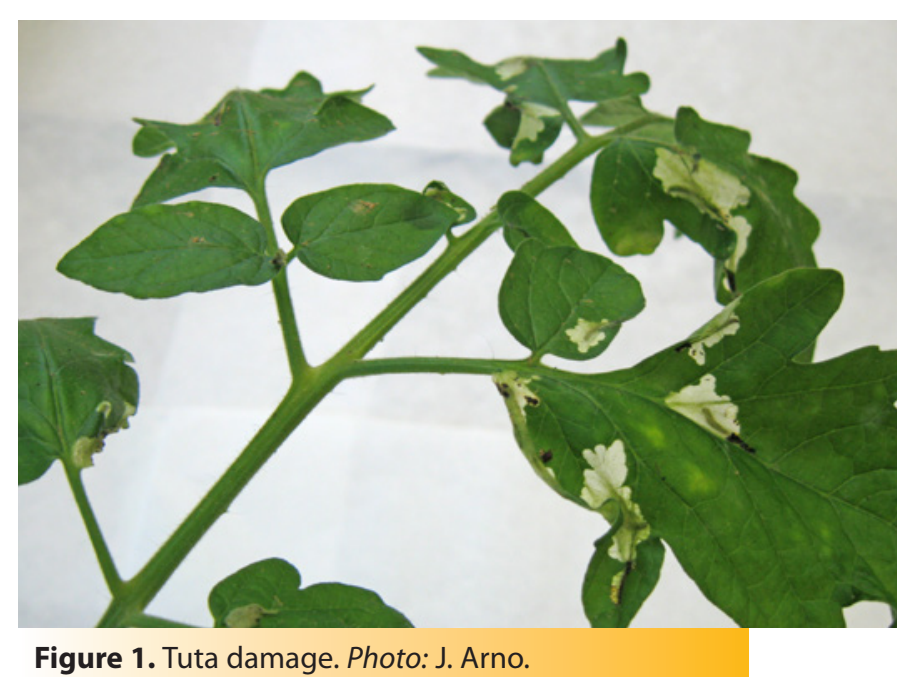
pest with climate and availability of host plants have predicted that Tuta has a moderate likelihood of establishing in the commercial tomato-growing regions of California, Arizona, and the southern United States (USDA 2011).

Tuta absoluta bores into tomato leaves, stems, flowers, apical buds, and fruit, resulting in less fruit set, poor plant structure, and unmarketable fruit. Crop losses can be as high as 80 to 100 percent, and insecticide costs may dramatically increase due to the need for additional insecticide applications (Lopez 1991; Estay 2000; Torres et al. 


\section{Host Plants}

Tuta absoluta prefers to feed, develop, and reproduce on tomato, but it can also use other solanaceous host plants (Desneux et al. 2010, 2011). Tuta will oviposit and develop on tomato, potato, black nightshade, eggplant, sweet pepper, jimsonweed, and deadly nightshade (Pereyra and Sanchez 2006; Desneux et al. 2010, 2011; Bawin et al. 2015). However, the number of eggs laid may be lower on some of the alternate hosts compared to tomato (Bawin et al. 2015). The rate of larval development may be slower and larval survival may be lower on some of the non-tomato crop plants and weed hosts (Bawin et al. 2015).

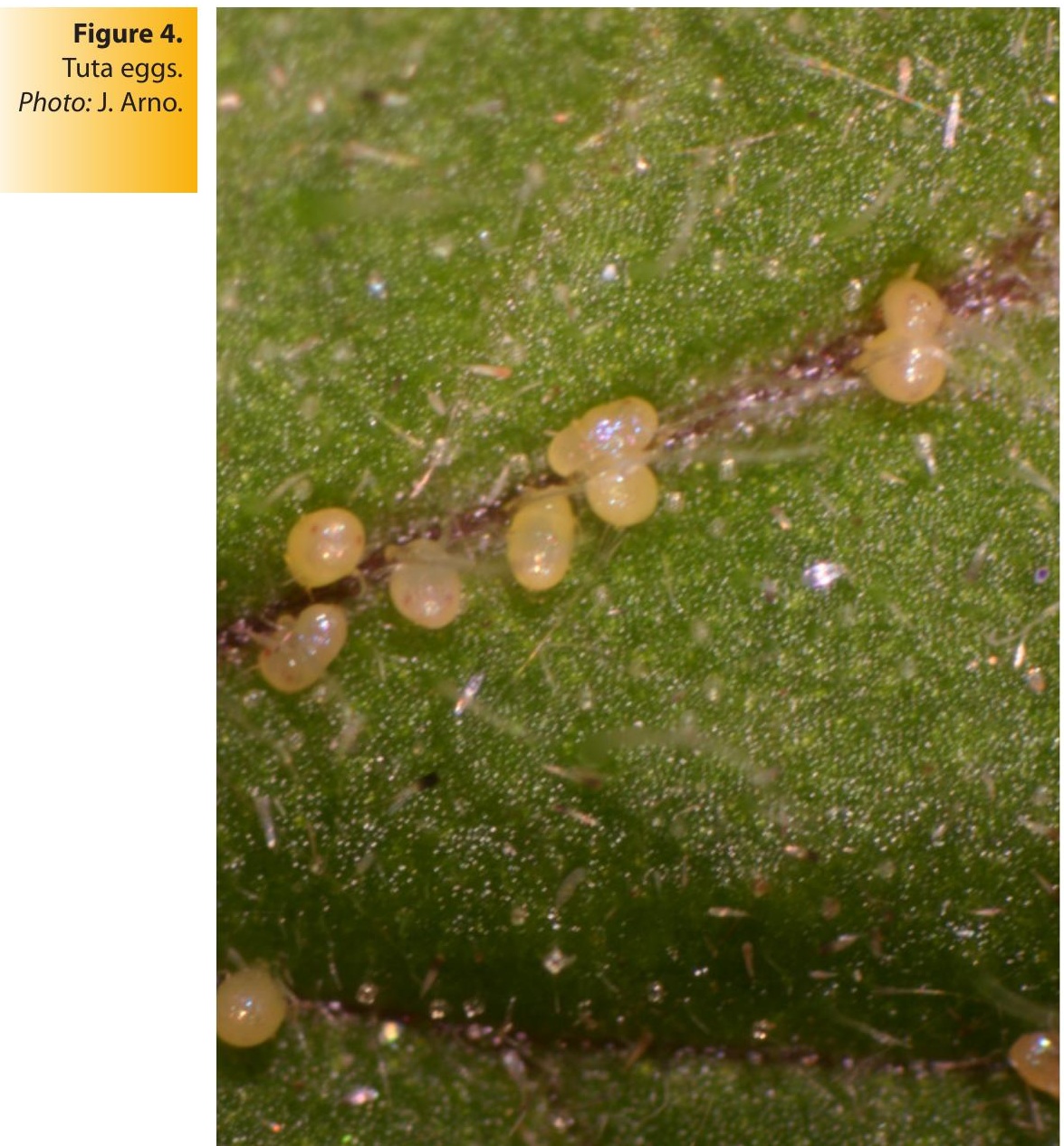

\section{Life CyCLE}

Tuta adults are small, grayish moths that are $3 / 16$ inch long. The male moths live on average 26 days and female moths live 24 days at $77^{\circ} \mathrm{F}$ (Fernandez and Montagne 1990). The female moths begin laying eggs 2 to 3 days after emergence (Fernandez and Montagne 1990) and may lay between 60 and 260 eggs in their lifetime (Torres et al. 2001; CABI 2011). Tuta females deposit their eggs either singly or in small clusters on the surface of leaves, stems, buds, flowers, and fruit (fig. 4) (Coelho et al. 1984; Torres et al. 2001). The newly laid eggs are cream colored to bright yellow and darken as the eggs mature (Imenes et al. 1990). The eggs hatch in 4 to 6 days at $80.6^{\circ} \mathrm{F}$ (Barrientos et al. 1998).

The newly emerged larvae burrow under the epidermis of the plant part on which the egg is laid. On leaves, stems, buds, and flowers, larval feeding creates mines that increase in length and width as the larva grows (Vargas 1970). Late second instar and third instar larvae can occasionally be found moving about the surface of the plant, possibly searching for additional food resources. This movement exposes these larvae to a variety of mortality agents (Miranda et al. 1998). In a heavily infested leaf, the leaf tissue is completely consumed and becomes skeletonized (fig. 5). Late second instar and third instar larvae can occasionally be found outside of the mine, moving about the plant for a short period of time before

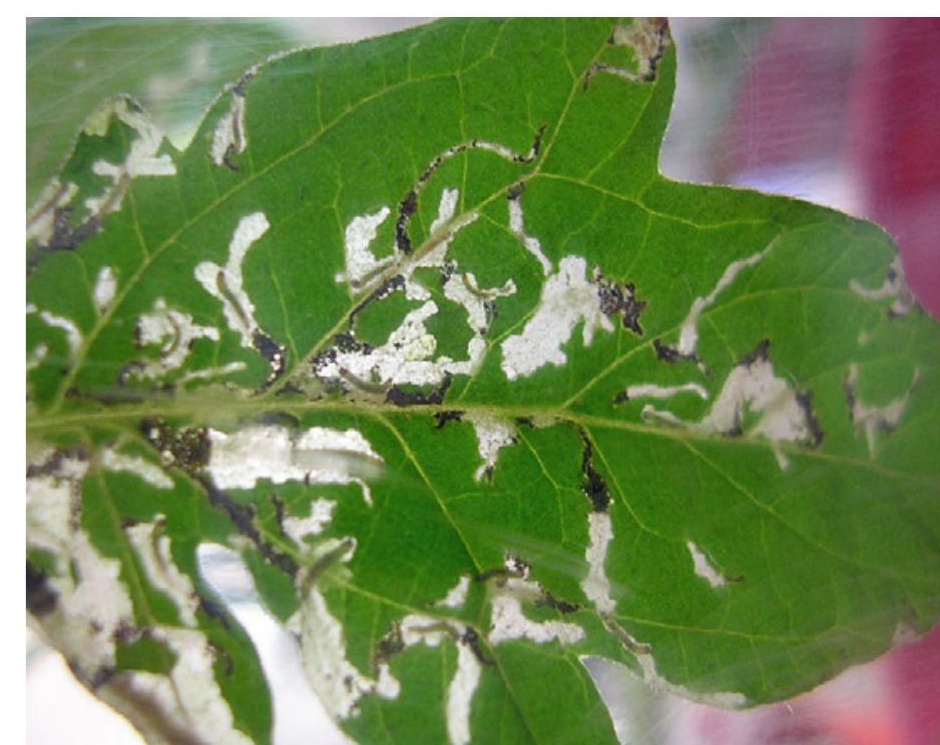

Figure 5. Leaf mines from Tuta. Photo: Marina Lee. 


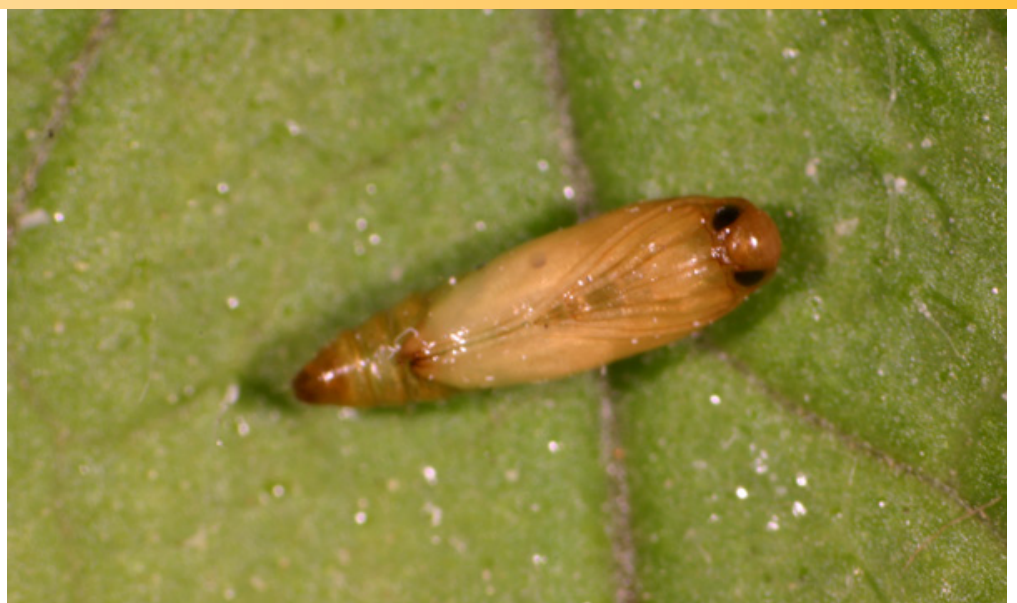

Figure 7. Tuta pupa. Photo: J. Arno.

burrowing back into the plant tissue. On fruit, the larva burrows into the fruit and feeds within a gallery (Vargas 1970). The larvae are cylindrical in shape with a distinct head and legs (fig. 6).

A larva completes four larval instars in 18 to 22 days at $80.6^{\circ} \mathrm{F}$ (Barrientos et al. 1998).

Prior to pupation, the fourth, or last, larval instar leaves the mine or fruit gallery and either drops to the soil surface or travels to the edge of a leaf, where it spins a silken cocoon in which to pupate (Vargas 1970; Barrientos et al. 1998). The pupa is oblong and brown (fig. 7) (Imenes et al. 1980). Adults emerge from the pupae in 5 to 8 days at $80.6^{\circ} \mathrm{F}$ (Barrientos et al. 1998).

The newly emerged female Tuta moths release a pheromone to attract a male moth for mating approximately a day after emerging from the pupae. This typically occurs around dawn (Vargas 1970). Female Tuta moths begin ovipositing about a day after mating (Fernandez and Montagne 1990). The moths are most active at dusk and dawn. During the day, they can be found resting on leaves and other plant parts. The moths are not considered strong fliers, although they may fly for short distances to find suitable hosts (Desneux et al. 2010).

Development from egg to adult requires 76 days at $57.2^{\circ} \mathrm{F}$ and 24 days at $80.6^{\circ} \mathrm{F}$ (Barrientos et al. 1998). Under warm environmental conditions, Tuta can complete up to 12 generations per year, but fewer can be expected in California. A degree-day model has been devised for Tuta; the lower developmental or baseline temperature for development from egg to adult is $46.7^{\circ} \mathrm{F}$
(Barrientos et al. 1998). Development from egg to adult requires 827.3 Fahrenheit degree-days above $46.7^{\circ} \mathrm{F}$ (Barrientos et al. 1998).

\section{DAMAGE}

Tuta larvae damage tomato plants by feeding in mines on leaves, stems, apical buds, and flowers and in galleries inside the fruit. In leaves, the larvae feed just below the leaf's surface and remove the plant cells responsible for photosynthesis. The mines may become so large that the leaf becomes skeletonized, reducing the plant's ability to photosynthesize and produce fruit (Desneux et al. 2010). The feeding on the buds and flowers can result in abscission of buds and flowers, reduction of plant growth, poor plant architecture, and a loss of fruit set (Desneux et al. 2010). Fruit may be attacked at any stage, and the galleries created by the larvae may be invaded by pathogens resulting in rotting fruit (Desneux et al. 2010).

Tuta absoluta damages both processing and fresh-market tomatoes. Yield loss caused by loss of leaf tissue or by direct larval feeding on the fruit is the most obvious economic damage imparted by Tuta. Management costs may also increase once Tuta is present because growers must monitor for the presence of Tuta and possibly increase the number of insecticide applications made to a crop. In addition, some processing tomatoes may be downgraded or not accepted by processors because of the presence of Tuta in a load of fruit. The California Department of Food and Agriculture (CDFA) has set standards for the quality of processing tomatoes, and any load that has "worm" damaged tomatoes "in excess of two percent 
by weight" can be rejected (CDFA 2016). Quarantines and other restrictions on the movement of tomato fruit and plants may be imposed both within California and the United States and with trading partners. This means that growers in affected areas may need to apply additional management measures before harvesting and moving fruit, may not be able to move fruit out of the area unless they comply with regulatory restrictions that may be enacted, or may experience a temporary loss of markets for their fruit outside of California.

\section{Monitoring And Management}

Since Tuta absoluta has yet to be detected in California or elsewhere in the Unites States, no specific monitoring or management guidelines have been developed. However, it is useful to relate experiences from other regions that it has invaded.

In the 1970s and 1980s, Tuta began to spread throughout the tomato growing regions of South America (Desneux et al. 2010). At that time, growers predominantly used insecticides to manage Tuta densities, and applications were made every 7 to 14 days (Lietti et al. 2005). This quickly led to insecticide-resistant populations of Tuta (Siqueira et al. 2000; Lietti et al. 2005). Current pest management programs rely on conservation of natural enemies, removal of alternate host plants, timing the insecticide applications based on Tuta pheromone trap catches and a degree-day development model, and consideration of the expected risk of damage to the tomato crop (Desneux et al. 2010). Pheromone trap catches were shown to be correlated with pest infestations and crop damage in one study (Benvenga et al. 2007). This approach substantially reduced Tuta management costs in infested areas of South America and reduced the impact of the insecticide applications for Tuta on other insect pests (Desneux et al. 2011).

Research on the role of natural enemies on the population dynamics of Tuta has shown that indigenous arthropod predators and insect parasitoids attack Tuta eggs and larvae shortly after invasion into a new area (Zappala et al. 2013). These natural enemies are mostly generalist feeders and are being opportunistic in using Tuta as a food source. Research is currently underway to exploit this opportunistic behavior of several species of the arthropod predators and insect parasitoids using multiple approaches, such as conservation or releases of the appropriate species of natural enemies (Zappala et al. 2013). Several of the species being studied are either found in California or have closely related species found in California.

Tuta absoluta was accidentally introduced into Spain in late 2006 (Urbaneja et al. 2007); despite quarantines, insecticide treatments targeting Tuta, and strict adherence to regulations, Tuta spread throughout the tomato-growing areas of Europe and North Africa in about 5 years (Desneux et al. 2010). It is thought that movement of Tuta was assisted by commercial trade of tomato plants and fruit despite the regulations. Eggs, very young larvae, or pupae may be present on tomato plants or in the fruit and escape detection since these life stages are extremely difficult to detect during inspections of plants or fruit. Tomato packing crates and other harvesting equipment may also harbor pupae or adult Tuta. Further, the insect may be moved by private individuals on infested plant material from home or community gardens (Desneux et al. 2010). Once present in an area, the moths can fly for short distances or possibly be carried by wind currents (Desneux et al. 2010). Similar scenarios could occur should Tuta be introduced into California.

\section{If You Think You Might Have Found Tuta in California}

If you suspect that you have found T. absoluta, place the suspect insect in a sealed container and contact your local county agricultural commissioner's office for identification. If the insect is confirmed to be T. absoluta, the extent of the infestation will be delineated and the appropriate regulatory actions will be taken to minimize the spread of Tuta from the infested site. Detection of Tuta very soon after its initial introduction into California will assist regulators and growers in implementing management tactics intended to limit the spread and impact of this pest. 


\section{References}

Barrientos, A., H. Apablaza, S. Norero, and P. Estay. 1998. Temperatura base y constant termica de desarrollo de la polilla del tomate, Tuta absoluta (Lepidoptera: Gelechiddae). Ciencia e Investigacion Agraria 25:133-137.

Bawin, T., D. Dujeu, L. DeBaker, M. Fauconnier, G. Lognay, P. Delaplace, F. Francis, and F. Verheggen. 2015. Could alternative solanaceous hosts act as refuges for the tomato leafminer, Tuta absoluta? Arthropod-Plant Interactions 9:425-435.

Benvenga, S., O. Fernandes, and S. Gravena. 2007. Decision making for integrated pest management of the South American tomato pinworm based on sexual pheromone traps. Horticultura Brasileira 25:164-169.

CABI (Centre for Agriculture and Bioscience International). 2016. Tuta absoluta. CABI website, https://www.cabi.org/isc/ datasheet $/ 49260$.

CDFA (California Department of Food and Agriculture). 2016. California Processing Tomato Inspection Program. Marketing Branch. CDFA website, www.cdfa.ca.gov.

Coelho, M., F. Franca, C. Cordeiro, and H. Yoshihiki. 1984. Biologia e distribuicao especial de ovos e minas da tracado-tomateiro. In Resumos do 24o Congresso Brasileiro de Olericultura. Jaboticabal: Sociedade Brasileira de Olericultura.

Desneux, N., M. Luna, T. Guillemaud, and A. Urbaneja. 2011. The invasive South America tomato pinworm, Tuta absoluta, continues to spread in Afro-Eurasia and beyond: The new threat to tomato world production. Journal of Pest Science 84:403-408.

Desneux, N., E. Wajberg, K. Wyckhuys, G. Burgio, S. Arpaia, C. Narvaez-Vasquez,J. Gonzalez-Cabrera, D. Ruescas, E. Tabone, J. Frandon, J. Pizzol, C. Poncet, T. Cabello, and A. Urbaneja. 2010. Biological invasion of European tomato crops by Tuta absoluta: Ecology, geographic expansion and prospects for biological control. Journal of Pest Science 83:197-215.
Estay, P. 2000. Polilla del tomate Tuta absoluta (Meyrick). Instituto de Investigationes Agropecuarias, Centro Regional de Investigacion La Platina, Ministerio de Agricultura, Santiago Chile. http://www2.inia.cl/medios/biblioteca/informativos/ NR25648.pdf

Fernandez, S., A. and Montagne. 1990. Biologia del minador del tomate, Scrobipalpula absoluta (Meyrick) (Lepidoptera: Gelechiidae). Boletin de Entomologia Venezolana 5:89-99.

Imenes, S., M. Uchoa-Ferandes, T. Campos, and A. Takematsu. 1990. Aspectos biologicos e comportamentais da trata do tomateiro Scrobipalpula absoluta (Meyrick 1917) (Lepidoptera: Gelechiidae). Arquivos do Instituto Biologico (Sa Paulo) 57:63-68.

Lietti, M., E. Botto, and R. Alzogaray. 2005. Insecticide resistance in Argentine populations of Tuta absoluta (Meyrick) (Lepidoptera: Gelechiidae). Neotropical Entomolology 34:113-119.

Lopez, E. 1991. Polilla del tomate: Problema critic para la rentabilidad del cultivo de verano. Empresa y Avance Agricola $1: 6-7$.

Miranda, M., M. Picanco,J. Zanuncio, and R. Guedes. 1998. Ecological life table of Tuta absoluta (Meyrick) (Lepidoptera: Gelechiidae). Biocontrol Science and Technology 8:597606.

Pereyra, P., and N. Sanchez. 2006. Effect of two solanaceous host plants on development and population parameters of the tomato leaf miner, Tuta absoluta (Meyrick) (Lepidoptera: Gelechiidae). Neotropical Entomology 35:671-676.

Siqueira, H., R. Guedes, and M. Picanco. 2000. Insecticide resistance in populations of Tuta absoluta (Lepidoptera: Gelechiidae). Agricultural and Fororest Entomology 2:147-153.

Torres, J., C. Faria, W. Evangelista, and D. Pratissoli. 2001. Within plant distribution of leaf miner Tuta absoluta (Meyrick) immatures in processing tomatoes, with notes on plant phenology. International Journal of Pest Management 47:173178. 
Urbaneja, A., R. Vercher, V. Navarro, F. Garcia Mari, and J. Porcuna. 2007. La polilla del tomate, Tuta absoluta. Phytoma Espana 194:16-23.

USDA (United States Department of Agriculture). 2011. New pest response guidelines: Tomato leafminer (Tuta absoluta). USDA Animal and Plant Health and Inspection Service website, https://www.aphis.usda.gov/import_export/plants/ manuals/emergency/downloads/Tuta-absoluta.pdf.

Vargas, H. 1970. Observaciones sobre la biologia y enemigos naturales de la polilla del tomate, Gnorimoschema absoluta (Meyrick) (Lepidoptera: Gelechiidae). Idesia 1:75-110.

Zappala, L., A. Biondi, A. Alma, I. Al-Jboory, J. Arno, A. Bayram, A. Chailleux, A. El-Arnaouty, D. Gerling, Y. Guenaoui, L. Shaltiel-Harpaz, G. Siscaro, M. Stavrindes, L. Tavella, R. Aznar, A. Urbaneja, and N. Desneux. 2013. Natural enemies of the South American moth, Tuta absoluta, in Europe, North Africa, and Middle East, and their potential use in pest control strategies. Journal of Pest Science 86:635-647.

\section{ACKNOWLEDGMENTS}

This publication was supported by the Specialty Crop Block Program at the U.S. Department of Agriculture (USDA) through Grant 14-SCBGP-CA-006. Its contents are solely the responsibility of the authors and do not necessarily represent the official views of the USDA.

\section{FOR FURTHER INFORMATION}

To order or obtain ANR publications and other products, visit the ANR Communication Services online catalog at http://anrcatalog.ucanr.edu/ or phone 1-800-994-8849. You can also place orders by mail or FAX, or request a printed catalog of our products from

University of California

Agriculture and Natural Resources

Communication Services

2801 Second Street

Davis, CA 95618

Telephone 1-800-994-8849

E-mail: anrcatalog@ucanr.edu
(C)2018 The Regents of the University of California. This work is licensed under the Creative Commons Attribution-NonCommercial-NoDerivatives 4.0 International License. To view a copy of this license, visit http://creativecommons.org/licenses/by-nc-nd/4.0/ or send a letter to Creative Commons, PO Box 1866, Mountain View, CA 94042, USA.

Publication 8589

ISBN-13: 978-1-62711-019-8

The University of California, Division of Agriculture and Natural Resources (UC ANR) prohibits discrimination against or harassment of any person in any of its programs or activities on the basis of race, color, national origin, religion, sex, gender, gender expression, gender identity, pregnancy (which includes pregnancy, childbirth, and medical conditions related to pregnancy or childbirth), physical or mental disability, medical condition (cancer-related or genetic characteristics), genetic information (including family medical history), ancestry, marital status, age, sexual orientation, citizenship, status as a protected veteran or service in the uniformed services (as defined by the Uniformed Services Employment and Reemployment Rights Act of 1994 [USERRA]), as well as state military and naval service.

UC ANR policy prohibits retaliation against any employee or person in any of its programs or activities for bringing a complaint of discrimination or harassment. UC ANR policy also prohibits retaliation against a person who assists someone with a complaint of discrimination or harassment, or participates in any manner in an investigation or resolution of a complaint of discrimination or harassment. Retaliation includes threats, intimidation, reprisals, and/or adverse actions related to any of its programs or activities.

UC ANR is an Equal Opportunity/Affirmative Action Employer. All qualified applicants will receive consideration for employment and/or participation in any of its programs or activities without regard to race, color, religion, sex, national origin, disability, age or protected veteran status.

University policy is intended to be consistent with the provisions of applicable State and Federal laws.

Inquiries regarding the University's equal employment opportunity policies may be directed to: John Sims, Affirmative Action Contact and Title IX Officer, University of California, Agriculture and Natural Resources, 2801 Second Street, Davis, CA 95618, (530) 750-1397. Email: jsims@ucanr.edu. Website: http://ucanr.edu/sites/anrstaff/Diversity/Affirmative_ Action/.

An electronic copy of this publication can be found at the ANR Communication Services catalog website, http://anrcatalog.ucanr.edu/.

UC This publication has been anonymously peer reviewed for technical accuPEER racy by University of California scientists and other qualified professionals. This review process was managed by ANR Associate Editor for Pest Management-Agricultural Brenna Aegerter.

web-1/18-SB/CR 